\title{
EFFECTIVENESS OF BLACK GLUTINOUS RICE ON METABOLIC SYNDROME IN ADULTS IN PARIAMAN DISTRICT, WEST SUMATERA
}

\author{
Eva Yuniritha, Rr. Nur Fauziyah, Osman Syarief, Kasmiyetti \\ Department of Nutrition, School of Health Polytechnics, Ministry of Health, Padang
}

\begin{abstract}
Background: Earlier studies have demonstrated that eating glutinous brown rice (GBR) for just 1 day improved the whole-day glucose profile compared with eating white rice (WR) or brown rice (BR), mainly by reducing postprandial glucose excursion, and GBR also overcame the problem of poor palatability of BR. Another studies confirmed that GBR was well tolerated for 8 weeks and improved glycemic control in patients with type 2 diabetes. This study aimed to effectiveness of black glutinous rice on metabolic syndrome in adults in Pariaman district, West Sumatera.

Subjects and Method: This was a randomized controlled trial conducted in Padang Pariaman, West Sumatera, Indonesia. A sample of 42 people with metabolic syndrome was selected for this study and divided into two groups: experiment group and control group. The dependent variables were components of metabolic syndrome, including increased blood triglyceride level, low HDL cholesterol level, blood pressure, and fasting blood sugar level. The independent variable was type of rice, either GBR or WR. Data on metabolic syndrome was measured by blood examination. Waist circumference was measured by Matlin. The data were analyzed by independent $t$ test.

Results: Waist circumference was shorter $(\mathrm{p}=0.001)$, triglyceride level was lower $(\mathrm{p}=0.007)$, HDL was higher $(\mathrm{p}=0.043)$, fasting blood glucose level was lower $(\mathrm{p}=0.001)$, systolic blood pressure was lower $(\mathrm{p}=0.004)$, and diastolic blood pressure was lower $(\mathrm{p}=0.026)$ in the GBR group than the control group.

Conclusion: Glutinous black rice is effective to improve metabolic syndrome clinical presentation.
\end{abstract}

Keywords: Black glutinous rice, metabolic, syndrom

\section{Correspondence:}

Eva Yuniritha. Department of Nutrition, School of Health Polytechnics, Ministry of Health, Padang. Jl. Raya Siteba Pondok Kopi, Padang, West Sumatera 25146.

Email : yunirithaeva2010@gmail.com. Mobile: 08126745364

The 5th International Conference on Public Health Best Western Premier Hotel, Solo, Indonesia, February 13-14, 2019 | 609 https://doi.org/10.26911/theicph.2019.05.08 